\title{
MODERN CHALLENGES OF AGRARIAN BUSINESS IN UKRAINE ON THE WAY TO EUROPE
}

\author{
Petro Putsenteilo, Full Professor'; Yuriy Klapkiv, PhD, Assistant Professor'; \\ Yaroslav Kostetskyi, PhD, Assistant Professor ${ }^{3}$
}

${ }^{1,3}$ Faculty of Agricultural Economics and Management, Ternopil National Economic University

${ }^{2}$ Faculty of Economics and Sociology, University of Lodz

\begin{abstract}
It is established that the Ukrainian agrarian sector in recent years suffered quite serious reformational impacts on the institutional environment of the functioning of economic actors, in particular the influence of regulators on the transformation of agricultural development. It is substantiated that under institutional transformations it is appropriate to understand the changes that occur as part of the creation of new rules of conduct of participants, containing a specific mechanism for ensuring compliance with these rules, as well as improving organizational and economic regulators within the existing set of rules for all participants It is determined that the institutional system is a structured set of interrelated informal rules that determine, on the one hand, a system of incentives for increasing the efficiency of interaction between subjects of the agrarian economy, and, on the other hand, restricts the activities of economic agents, which create a certain framework for implementation their target functions in accordance with the law and public interests.
\end{abstract}

Keywords: agrarian sector, agro-industrial complex, agricultural enterprises, institutional structures, EU economic policy, export

JEL codes: Q100, Q130, Q170

\section{INTRODUCTION}

The aim of the article is to substantiate the scientific principles of the development of the agrarian business of Ukraine in modern conditions: the state of development of agrarian business of Ukraine; export opportunities of Ukraine and factors hindering the growth of export of products; conditions and prospects of implementation of export policy of Ukraine; prospects of development of agrarian business of Ukraine in the direction of export.

In today's world globalization processes, the most countries of the world position themselves as open economies, the dynamics of which depends on the development of effective foreign economic relations of economic entities, in particular agrarian business. Exports in the open economy are an instrument for ensuring the expansion of the market space for the

${ }^{1}$ Corresponding author: Lvivska 11, Ternopil, Ternopil region 46020, Ukraine, p.putsenteilo@tneu.edu.ua, +38 (035) 2475050

${ }^{2}$ Corresponding author: Polskiej Organizacji Wojskowej 3/5, 90-255 Łódź, Poland

${ }^{3}$ Corresponding author: Lvivska 11, Ternopil, Ternopil region 46020, Ukraine 
development of industries and industries ready for intense international competition. Given the natural resource, social and economic, national and cultural background, one can state that for Ukraine one of these industries is an agrarian business that is capable of providing significant currency and investment revenues for the expanded reproduction of the national economy and to create conditions for integration into the world economy as an equal and strategically important partner.

The development of the agrarian sector of Ukraine's economy during 1991-2018 has undergone two main directions: the decline of livestock sectors, intensification of crop production and an increase in the export of agricultural products. Since the early 2000s, most agricultural enterprises are engaged in the growing crop production. The emphasis is placed on crops in this area that are export and investment attractive: wheat, barley, corn, sunflower, soybean, rape (Sabluk and Kodenska, 2012). Favourable soil-climatic conditions, macroeconomic factors of production and demand for these products in the world are the general preconditions for this. Due to this policy, there was a significant increase in the income of agrarian units, increased the stability of their financial situation and formed the prerequisites for further investing in the technical re-equipment of enterprises.

In recent years, the application of genetic modification and other modern biotechnologies in animal and plant breeding has been a prominent issue in public debates. This is because concerns over modern biotechnologies transcend regulators' traditional risk assessment strategies. Indeed, they call for the explicit inclusion of ethical considerations when formulating public policies. In turn, this suggests that there is a need to develop appropriate ethical assessment tools (Beekman, Bakker and Sandoe, 2006).

The importance of discussing issues of sustainability with respect to food production is almost evident. Sustainability is on the public agenda and will not easily disappear. It has become an issue widely debated in many countries, and many organizations such as the FAO and retail multinationals have their own sustainable development department (Brom, Visak and Meijboom, 2007; Meijboom, and Brom, 2011).

\section{MATERIAL AND METHODS}

The data used for documenting the paper was collected mainly through desk research. Different information sources from European and national level, such as reports, country fact sheets and articles were consulted.

The work included an analysis of available Ukrainian and foreign scientific literature on the development of agrarian business and export of products. The criterion for choosing a literature for consideration was the current and potential impact of the dynamics of agricultural production and exports, taking into account the activity of agricultural enterprises and households (small businesses). The main aim of the study was to compare the diversity of agrarian structure and land productivity in Ukraine. The analysed changes in the agrarian structure concern, among other things, the structure of the number of farms and the structure of production in farms. The main export commodity positions of agrarian products are determined.

The ratio of gross added value of agriculture in producer prices to measure the costs and resources of productive factors was taken in this study to determine the productivity of land and labour. As for the land, the size of the agricultural land in hectares (ha) was adopted, while the volume of production in tonnes (million tonnes) and centners of one hectare (c/ha). The methods of induction and deduction, the method of expert Estimates were used. The daily range of analyses covered the years 2010-2017.

\section{RESULTS AND DISCUSSIONS}

\section{The agrarian business of Ukraine}

There are main groups of producers of agricultural products in agriculture of Ukraine: agricultural enterprises, farms, households:

- agricultural enterprises are enterprises that operate mainly on leased land and oriented to commodity production. This category includes joint-stock companies and subsidiary companies, private companies controlled by an entrepreneur-owner of private assets, etc. 
- this category comprised about 12,000 enterprises in 2018, including small forms of economic activity, which carried out economic activities in the reported year and they employ approximately $60 \%$ of agricultural land value;

- farms are a form of entrepreneurial activity of citizens who have expressed a desire to produce commodity agricultural products, to carry out their processing and realization in order to generate profit on land plots given to them by property and/or use, including lease, for the management of a farm, commodity agricultural production, personal peasant economy, in accordance with the law. At present, this category has about 33,500 farms, which cultivate up to $10 \%$ of agricultural land;

- households - households engaged in agricultural activity both for self-provision of food products and for the purpose of production of commodity agricultural products; this category of producers is also referred to as individual entrepreneurs who carry out their activities in the field of agriculture; in 2017, the circle of households accounted for about 6.1 million households, processing 30\% of agricultural land (Putsenteilo and Kostetskyi, 2017).

Setting new agricultural policies or measures to support farms requires monitoring income stability and variability as indicators of farm production conditions (Zgajnar, 2013).

The number of produced agricultural products of Ukraine is shown in Tables 1 and 2.

There are many studies where there is an analysis of agricultural production at the farms and sector level (Vrolijk and Poppe, 2008; Mary, Santini and Boulanger, 2013; Finger and El Benni, 2014).

\section{The state of development of agrarian business of Ukraine}

According to the data of State Statistics Service of Ukraine, in Ukraine, the area of agricultural land is almost 36.5 million ha, of which more than 20.7 million ha are located in agrarian enterprises (99\% are registered according to land lease agreements). The remaining $43.1 \%$ (or 15.7 million ha) are owned by the population. However, $75 \%$ of businesses are involved in the business, since 5 million ha of land are used by the population for construction, maintenance of residential and commercial buildings, as well as subsidiary farming; about the same part by structural grouping belongs to the hayfields and pastures.

According to the data of State Statistics Service of Ukraine, the main part of the crops is occupied by crops of the grain group (55\% or 15 million ha): wheat (45\%), corn for grain (28\%), barley $(17 \%)$ and other crops (10\%).

According to the data of State Statistics Service of Ukraine, among the technical crops, the most popular are oilseeds: sunflower, soybean and rape. Today technical crops occupy 8.8 million ha or $33 \%$. Sunflower is sown on an area of 6 million ha in 2017; soybeans -2.3 million ha; rape -0.8 million ha; sugar beet -0.5 million ha.

According to the data of State Statistics Service of Ukraine, in 2016, the production of grain crops was 66 million tonnes (2.7 times higher than in 2000). Wheat -26 million tonnes; corn for grain -28 million tonnes; barley -9.2 million tonnes; rye 392 thousand tonnes; oats -500 thousand tonnes; buckwheat -180 thousand tonnes; peas -760 thousand tonnes; rice -65 thousand tonnes. This was due to the intensification of cultivation technologies, which influenced the increase in yield, since the area under grain and leguminous crops declined by 390 thousand ha (or $2.7 \%$ ).

The average yield in all group was $46.1 \mathrm{c} / \mathrm{ha}$ (more by $5.0 \mathrm{c} / \mathrm{ha}$ than in 2015). The crop yield after crops became: wheat $-42.1 \mathrm{c} / \mathrm{ha}$; corn for grain $-66 \mathrm{c} / \mathrm{ha}$; barley $-33 \mathrm{c} / \mathrm{ha}$; rye $-27.3 \mathrm{c} / \mathrm{ha}$; oats $-23.9 \mathrm{c} / \mathrm{ha}$; buckwheat $-11.5 \mathrm{c} / \mathrm{ha}$; peas c/ha; $31.3 \mathrm{c} / \mathrm{ha}$; rice $54 \mathrm{c} / \mathrm{ha}$.

According to the data of State Statistics Service of Ukraine, among technical crops, the first place in the structure of production is sunflower, the share of which is $2 / 3$ in this group of crops. In 2016, sunflower seeds have been produced in the amount of 13.6 million tonnes. In recent years, the agrarian enterprises have increased their attention to sugar beets, whose yield was $482.4 \mathrm{c} / \mathrm{ha}$. Potato production amounted to 21 million tonnes at yield of $160.7 \mathrm{c} / \mathrm{ha}$, vegetables grown 9 million tonnes at a yield of $220 \mathrm{c} / \mathrm{ha}$. 
Proceedings of the 2018 International Scientific Conference 'Economic Sciences for Agribusiness and Rural Economy' No 1, Warsaw, 7-8 June 2018, pp. 250-258

Table 1. Agricultural production of Ukraine in 2010 prices (UAH million)

\begin{tabular}{|c|c|c|c|}
\hline \multirow{2}{*}{ Year } & \multicolumn{3}{|c|}{ All agricultural holdings } \\
\cline { 2 - 4 } & agricultural production & \multicolumn{2}{|c|}{ of which } \\
\cline { 2 - 4 } & & crop production & animal production \\
\hline 2010 & 187526.1 & 120591.4 & 66934.7 \\
\hline 2011 & 225381.8 & 157561.9 & 67819.9 \\
\hline 2012 & 216589.8 & 145843.6 & 70746.2 \\
\hline 2013 & 246109.4 & 172131.2 & 73978.2 \\
\hline 2014 & 251427.2 & 177707.9 & 73719.3 \\
\hline 2015 & 239467.3 & 168439.0 & 71028.3 \\
\hline 2016 & 254640.5 & 185052.1 & 69588.4 \\
\hline 2017 & 249157.0 & 179474.6 & 69682.4 \\
\hline
\end{tabular}

Source: State Statistics Service of Ukraine data.

Table 2. Agricultural production enterprises and households of Ukraine in 2010 prices (UAH million)

\begin{tabular}{|c|c|c|c|c|c|c|}
\hline \multirow{3}{*}{ Year } & \multicolumn{3}{|c|}{ Agricultural enterprises } & \multicolumn{3}{|c|}{ Households } \\
\hline & \multirow{2}{*}{$\begin{array}{l}\text { agricultural } \\
\text { production }\end{array}$} & \multicolumn{2}{|c|}{ of which } & \multirow{2}{*}{$\begin{array}{l}\text { agricultural } \\
\text { production }\end{array}$} & \multicolumn{2}{|c|}{ of which } \\
\hline & & crop production & $\begin{array}{l}\text { animal } \\
\text { production }\end{array}$ & & crop production & $\begin{array}{c}\text { animal } \\
\text { production }\end{array}$ \\
\hline 2010 & 90792.0 & 64860.6 & 25931.4 & 96734.1 & 55730.8 & 41003.3 \\
\hline 2011 & 117110.9 & 89572.9 & 27538.0 & 108270.9 & 67989.0 & 40281.9 \\
\hline 2012 & 110071.7 & 80462.6 & 29609.1 & 106518.1 & 65381.0 & 41137.1 \\
\hline 2013 & 133683.1 & 101297.0 & 32386.1 & 112426.3 & 70834.2 & 41592.1 \\
\hline 2014 & 139058.4 & 105529.5 & 33528.9 & 112368.8 & 72178.4 & 40190.4 \\
\hline 2015 & 131918.6 & 99584.7 & 32333.9 & 107548.7 & 68854.3 & 38694.4 \\
\hline 2016 & 145119.0 & 113392.6 & 31726.4 & 109521.5 & 71659.5 & 37862.0 \\
\hline 2017 & 140535.2 & 108601.1 & 31934.1 & 108621.8 & 70873.5 & 37748.3 \\
\hline
\end{tabular}

Source: State Statistics Service of Ukraine data.

The number of animals contained 3.7 heads of cattle (2.1 million heads of cows) in 2016; 6.7 million heads of pigs and 1.3 heads of sheep and goats. The situation with poultry is an exception to animal husbandry. Its livestock enhances and since 2000 increased from 123.7 million head to 202.4 million head in 2016. This indicates the stable work of the poultry farm, especially with the growth of chickens and egg production. Another feature of this industry is the structure of the existing stock by categories of economic entities, where the share of farms remains tangible.

After all, agricultural enterprises, especially large holding associations, do not want to engage in livestock breeding. This is confirmed by the data on the reduction of their share of cattle from 53.4\% in 2000 
to $33.0 \%$ in 2016 ; sheep and goats - respectively from 22.0 to $14.3 \%$. According to data of State Statistics Service of Ukraine, exception is the pig and poultry industry, where the share increased from 31.5 to $53.4 \%$ and from 20.5 to $54.7 \%$.

In 2016 agrarians produced 2,300.9 thousand tonnes of meat (all types) in slaughter weight, which is $38.3 \%$ more than in 2000 . But in the structure of this volume $49.3 \%(1,135.7$ thousand tonnes $)$ is poultry meat, although in 2000 it occupied only $11.6 \%$. According to the data of State Statistics Service of Ukraine, most of the meat in Ukraine is produced by agrarian enterprises - almost $62 \%$.

Compared to 2000, their share increased by 2.3 times. The volume of milk production in 2016 amounted to 10,387.2 thousand tonnes. The farms in poultry farming reached the largest increase in production volumes. Today they produce $15,113.5$ million pieces eggs that by 1.7 times more than in 2000 . It should be noted that poultry production is the most stable and profitable business in comparison with other branches of industry, which is confirmed by the share of production of enterprises.

Consequently, the volume of industry is currently equal to the actual level of solvent consumption. Therefore, it should be noted from the point of view of the consumption and export potential of the agricultural sector that the livestock sector is developing unevenly, especially as it concerns livestock, pig farming and other industries for the growing small domestic animals.

\section{Export opportunities of Ukraine}

43.02 million tonnes of grain was exported in the $2016 / 2017$ marketing year, which is 5 million tonnes more than in the 2015/2016 marketing year. Grain crops (at the expense of corn and wheat), oilseeds (primarily soybean), oil (mainly sunflower) and products of the food industry occupy definitive positions in the commodity structure of Ukrainian agri-food exports. Their total share exceeds $90 \%$ in agrarian exports. In 2016, Ukraine exported maize for USD 2.65 billion or 17.4 million tonnes. Egypt, Iran and Spain included the first three main importers, while the volume of these countries amounted to 2.9 million, 2.1 million and 1.8 million tonnes, respectively.
In the 2016/2017 marketing year, external deliveries of wheat amounted to 13.33 million tonnes, which is 1.78 million tonnes more than the same period of the last marketing year. Traditionally, the largest foreign consumer of Ukrainian wheat grain was India (3.3 million tonnes) (State Statistics Service of Ukraine, 2018).

Prospects for the development of export potential of Ukrainian wheat were due to several factors, including high interest rates for agricultural producers (farmers forced to quickly sell grain at low prices to increase liquidity), non-transparent terms of refund of export VAT and Memorandum of Understanding with grain exporters. The logistical problems within the country was one more reason, in which traders tried to take more wheat before entering the market of a large corn harvest, which is more attractive to them for the level of profitability of the business.

For export directed 32 thousand tonnes of flour. In 2016, more than 4.8 million tonnes of grain was exported to Ukrainian barley for an amount of USD 668 million. During January-May 2017, Ukraine exported 946 thousand tonnes of barley for an amount of USD 138.8 million (State Statistics Service of Ukraine, 2018).

The main buyer of this grain crop in the world market in 2016 became Saudi Arabia, which accounted for $42 \%$ of all exports of barley and a large party went to Libya $-17 \%$. The third position among importers of Ukrainian barley to China is $6.5 \%$. In the last 5 years, Saudi Arabia was the main buyer of barley from Ukraine, buying more than $60 \%$ of total exports. This grain crop is the main fodder crop for the country, which explains the steadily high level of its consumption. Regarding export prospects, according to analytical data, the world's production of barley is projected to decline, which will amount to 6.9 million tonnes in relation to last year (State Statistics Service of Ukraine, 2018).

The main buyers in the export market are the State Food and Grain Company of Ukraine, which leads the overall rating of exporters of agrarian and industrial complex with a total export share of agricultural products in $20 \%$. NIBULON exported goods by UAH 15.6 billion in 2016, in particular wheat exports by UAH 5.4 billion and sunflower seeds with a 
share of $43 \%$. The main export positions of NIBULON are wheat (36\%), corn (31\%), barley (12\%), the rest are seeds of sunflower and rape, grain sorghum. The main exporter of maize in 2016 is the agricultural holding, Kernel almost $10.4 \%$ of Ukraine's total exports of this crop (State Statistics Service of Ukraine, 2018).

The agrarian business of Ukraine is experiencing an obstacle for the export of products. With regard to the European integration of agrarian exports, a rather promising market in Europe of almost 480 million consumers was rather abusive for Ukrainian exports. Unlike the well-developed Asian market, where for the Ukrainian wheat, the Indian importer initially reduced import duties for products from 25 to $10 \%$, and in December 2016 this fee was completely abolished the European market is rather rigid and limited.

In the first quarter of 2017, Ukraine fully utilized all duty-free quotas for export to the EU for the main groups of goods for the entire 2017: quotas for sugar, maize, natural honey, cereals and flour, grape and apple juices, and poultry meat (State Statistics Service of Ukraine, 2018).

\section{Conditions and prospects of implementing the export policy of Ukraine}

One of the conditions for the use of autonomous trade preferences and free trade area is the establishment of quotas for the duty-free import of products of Ukraine and the EU into each other's markets. In accordance with the bilateral agreements, quotas are an additional element of trade liberalization. They are set on goods, the export of which to the EU or Ukraine market provides for the collection of customs duties and allows the import of parts of the exported products (within the limits of the approved quota volume) without payment of the duty. After the exhaustion of the quota volume, products may continue to be exported by Ukraine and EU markets each other, but already with the duty.

That is, quotas actually create additional favourable conditions for the export of certain types of products. The mechanism of quota regulation of duty-free import of agricultural products to the EU envisages regulation in two directions: 'the first buyer came the first is served' - provides for preliminary approv- al of quota volumes and their use depending on the available balance; - 'import licensing' - provides for the submission by importers of Ukrainian products of the relevant applications for import to the Directorate General of the European Commission 'Agrarian issues and rural development' and their gradual filling in.

Almost all quotas for agricultural products exported from Ukraine to the EU relate to raw materials. Their main purpose is to provide the processing industry of the EU countries with cheaper raw materials. In some cases, quotas have certain time intervals within which exports can be made. These time intervals help to avoid overflow of commodity markets and prevent 'collapse' of product prices.

Thus, the introduction of quotas for the duty-free export of Ukrainian products to the $\mathrm{EU}$ is a rational economic calculation, which, on the one hand, creates additional favourable conditions for the trade of Ukrainian producers in the EU market, and on the other hand, it provides the needs of the economies of its member countries in cheap raw materials under conditions, which reduces the risks of unfavourable price fluctuations.

Now introduction of systems for the identification of product quality by the HACCP system (Hazard Analysis and Critical Control Points - Hazard Analysis and Critical Control Points) is very important for the Ukrainian Agribusiness, which big business must definitely implement, and by 2019 - all entities (not only manufacturers, but also operators of the food market and implementers). It is quite expensive radical changes, but these changes will pay off or quotas? For further threat to Ukrainian exports represents a pan-European political direction, when the 'acceptable' importers will be established despite possible significant losses. How it happened with the closure of the Russian market.

Classic producers of agricultural products in Ukraine, almost not covered by the insurance protection (Klapkiv, 2016), due to the undeveloped insurance market and weak demand for insurance protection (Vakun, Klapkiv and Niemczyk, 2017). State subsidies that would have reduced the cost of insurance protection and ensure the continuity of reproduction are virtually absent. 
Therefore, an alternative to Ukraine is a segment of organic production. This will allow you to get additional quotas for the duty-free sale of products in the European market. In any case, the European integration of the agrarian market involves the implementation of standards and requirements for the quality of products, and, as practice shows, high potential of Ukrainian sowing material, for example, wheat, ultimately - in finished products, except for feed class on their scale and does not deserve. Thus, organizational, technical and technological changes are inevitable.

Therefore, it is necessary to put the bar a little higher and create effective conditions, including investment, for the widespread development of organic production that is priority for the European consumer. Consequently, the main preconditions for the effective development of agrarian exports of the Ukrainian economy are the formation of efficient agricultural land use and improvement of logistics.

Ukraine and the EU are important trading partners. Their total amount for 2016 amounted to over EUR 5.6 billion in the segment of trade in agricultural food products. At the same time, the trade balance is positive for Ukraine, the export of which within the segment is EUR 4.1 billion, compared to EUR 1.5 billion of imports from the EU. As a result, Ukraine ranks eighth among the importers of agricultural products to the EU and is only 21 st among the areas of export of products from this group of EU countries. Export volume in the range of EUR 4 billion (3.8-4.1) over the past five years is relatively stable and since 2013 maintains upward trend.

The average growth rate is about $2 \%$ annually. More than $85 \%$ of the total volume is raw materials. Basically it is grain and oil crops. The total exports of livestock products from Ukraine to the EU amounted to EUR 142 million (3.5\% of the total exports of agricultural food products). Of these, $1.9 \%$ belongs to the dairy group, $1.5 \%$ is for meat and offal (mainly chicken), the rest - for live animals and livestock products. In this context, it is important to characterize the terms of trade between these trading partners, since this is precisely what the prospects for further increasing the volume of trade and strengthening cooperation.
Ukraine and the EU are currently in the process of deepening international cooperation, which is being implemented within the Association Agreement. Accordingly, from 1 January 2016 the Agreement on an In-depth and Comprehensive Free Trade Area of Ukraine-EU entered into force. The terms of the agreement provide for the gradual (within 10 years) the abolition of import duties on most goods imported to the markets of each other, the introduction of unified rules for determining the origin of goods, bringing Ukraine their technical regulations, procedures and phytosanitary measures for the safety of food products in accordance with European and other conditions for establishing the most favourable access to their markets.

For a long time, a significant volume of commodity nomenclature between the named partners is implemented within the General System of Preferences (GSP). According to it, on more than 400 groups of goods, import duty rates are lower than in the FTA. In addition, in April 2014, the EU unilaterally introduced for Ukraine a mode of autonomous trade preferences, which provided for the abolition of import duties by $94.7 \%$ of the total volume of industrial goods and $83.4 \%$ of Ukrainian agricultural produce. As a result of these actions, the EU tariffs on imports of Ukrainian products declined from 4.9 to $0.5 \%$ on average, which, taking into account volumes of goods turnover, averagely reduced from 5 to $2.6 \%$ (State Statistics Service of Ukraine, 2018).

Consequently, products with a low level of processing and added value predominate in agricultural exports to the $\mathrm{EU}$, while the share of ready-made food products is still insignificant. The same applies to other areas for promotion of agrarian products to world food markets. In this regard, it should be recognized that the raw material orientation of Ukrainian exports makes Ukraine's position on foreign markets vulnerable, since the demand for commodities is volatile and characterized by significant seasonal price volatility. According to Anton (2008), agricultural support policies have a significant role in risk management, even if not directly oriented towards reducing risk; our research confirmed this finding.

Therefore, it is necessary to ensure an increase in the export of Ukrainian goods with high added value. 
An important factor in increasing agricultural exports with high added value to EU countries is to increase the requirements for the safety and quality of food and raw materials through the introduction of quality management systems and food safety management systems at enterprises. Implementation of the Association Agreement between Ukraine and the EU can become an effective tool for improving the terms of trade with the EU and the work of the agricultural sector as a whole.

That the relevance of professional moral autonomy arises from the combination of three elements. First, the increasing distance in time and space between consumer and farmer, which implies that society has to rely on farmers in many matters of agriculture because they lack the expertise and time to control all activities in the agro-food sector. Second, the presence of a number of ethical issues on the public agenda that are not (yet) governed by laws and lack a shared moral understanding in society. Third, we have clear indications that farmers have moral beliefs and values that enable them to contribute to the public debate in a relevant way and that they increasingly are willing to contribute to the debate on, for instance, animal welfare, nature management or sustainable food production. Consequently, it can be possible and relevant to entrust farmers with professional freedom in moral matters (Meijboom and Stafleu, 2015).

According to scientist Paul B. Thompson 'It is only in our own time that it has become necessary to formulate ideals that express our hope for the fate of the earth itself. The ideal of a local food community is a very new kind of agrarian ideal. At best, it anchors our hope by expressing (and, through material practice, cultivating) the first-person plural perspective that licenses the use of words such as we and our and orients hope toward the sustainability of the soil, the earth, that binds our practice together' (Thompson, 2010).

\section{CONCLUSIONS}

The development of a strategy of foreign economic activity should be a prerequisite for successful development for agricultural enterprises, which is a set of perspective plans and tasks that need to be implemented to achieve the goals. Particular attention in such strategy should be paid to the development of rules and behaviour of commodity producers in the foreign market in the role of the exporter and importer of goods and services. The following actions must be taken to expand the markets and successfully promote domestic agricultural products to the world food markets:

- to concentrate efforts on increasing the efficiency of production of traditional export products for Ukraine (grain crops, sunflower, livestock products) and increase the presence in promising sectors of the world food market in areas such as rape, sugar beet, flax, fruits and berries, with their industrial processing for sale abroad;

- to diversify the geographical structure of foreign trade in agricultural products (especially exports), while minimizing the dependence on individual from certain states regarding the import of certain types of agricultural products;

- to ensure, the balance of exports and imports of agricultural products at the state level, to seek increasing the surplus in foreign trade;

- to reorient the development of the agrarian sector economy gradually to increase the export potential with the condition of maintaining the balance between domestic and external demand for agricultural production.

Given the significant contribution of the agrarian sector to the Ukrainian economy, state support should be optimized taking into account macroeconomic indicators of development. This involves the inclusion of new intensely innovative factors of economic growth that meet the challenges of the long-term period, which will ensure the output of the domestic agrarian business on the trajectory of sustainable growth in the range of $6-8 \%$ per year. Successful implementation of the set tasks depends on ensuring the sustainable development of the industry on the basis of knowledge-based approaches and innovative solutions.

The conducted studies allowed to identify factors hindering the growth of export of agribusiness products:

- shortage of working capital and high cost of credit resources for agrarian business; 
- high cost of technical equipment, fertilizers, fuel, which influences the increase of the share of variable costs in the structure of the cost of production;

- currency risks and the dynamic conditions of the global agro-food market - increased competition and volatility of prices;

- instability of tax legislation, corruption and increase of tax burden, absence of effective state support mechanisms.

\section{REFERENCES}

1. Anton, J. (2008). Agricultural policies and risk management: a holistic approach. In: Berg, E., Huirne, R., Majewski, E., Meuwissen, M. (eds.) Income stabilisation issues in a changing agricultural world: policy and tools. Wieś Jutra, Warszawa, pp. 15-28.

2. Beekman, V., Bakker, E., Sandoe, P. (2006). Ethical BioTechnology Assessment Tools for Agriculture and Food Production. Final Report Ethical Bio-TA Tools (QLG6CT-2002-02594) Retrieved from https://www.researchgate.net/publication/40110288 [Accessed 18.03.2018].

3. Brom, F.W.A., Visak, T., Meijboom, F.L.B. (2007). Food, citizens, and market, the quest for responsible consuming. In: Frewer, L., van Trijp, H. (eds.) Understanding consumers of food products. Cambridge, Woodhead, pp. 610-623.

4. Finger, R., El Benni, N. (2014). Alternative Specifications of reference Income Levels in the Income Stabilization Tool. In: Zopounidis, C., Kalogeras, N., Mattas, K., van Dijk, G., Baourakis, G. (eds.) Agricultural Cooperative management and Policy. New Robust, Reliable and Coherent Modelling Tools. Springer International Publishing, Switzerland, pp. 65-85.

5. Klapkiv, Y. (2016). A Strategy of institutional development in the market of insurance. Scientific Bulletin of Polissia, N4 (1), pp. 132-136.

6. Mary, S., Santini, F., Boulanger, P. (2013). An Ex-Ante Assessment of CAP Income Stabilisation Payments Using a Farm Household Model. In: 87th Annual Conference of the Agricultural Economics Society, in April in Warwick, p. 13.
7. Meijboom, F.L.B., Brom, F.W.A. (2012). Ethics and Sustainability: Guest or Guide? On Sustainability as a Moral Ideal. Journal of Agricultural and Environmental Ethics, 25, pp. 117-121. Retrieved from: https://www. researchgate.net/publication/251302912_Ethics_and Sustainability_Guest_of_Guide_On_Sustainability_ as_a_Moral_Ideal [Accessed 19.03.2018].

8. Meijboom, F.L.B., Stafleu, F.R. (2015). Farming ethics in practice: from freedom to professional moral autonomy for farmers. Agriculture and Human Values, 33 (2). DOI 10.1007/s10460-015-9641-8. Retrieved from: https://www.researchgate.net/publication/280932098 [Accessed 19.03.2018].

9. Putsenteilo, P., Kostetskyi, Ya. (2017). Institutsional'ne seredovishche ta institutsii funktsionuvannya agrarnogo sektoru Ukraini v umovakh transfor [Institutional environment and institutions of the functioning of the agrarian sector of Ukraine in the conditions of transformation processes]. Innovative Economy, 7-8 (70), pp. 28-38. Retrieved from: http://dspace.tneu.edu.ua/handle/316497/28865 [Accessed 29.03.2018].

10. Sabluk, P., Kodenska, M. (2012). Conceptual principles of development and implementation of investment programs in agrarian business. IAE, Kyiv.

11. Thompson, P.B. (2010). The Agrarian Vision: Sustainability and Environmental Ethics. University Press of Kentucky, Lexington. Retrieved from: https://books. google.com.ua/books? id=RfpVBrEJkisC\&printsec $=$ fro ntcover\&hl $=$ uk\&source $=$ gbs_ge_summary_r\&cad $=0 \#$ $\mathrm{v}=$ onepage \&q\&f=false [Accessed 19.05.2018].

12. Vakun, O., Klapkiv, Y., Niemczyk, L. (2017). Financial mechanism of the insurance business. Scientific Bulletin of Polissia, 2, 4 (12), pp. 84-91.

13. Vrolijk, H.C.J., Poppe, K.J. (2008). Income volatility and income crises in the European Union. In: Meuwissen, M.P.M., van Asseldonk, M.A.P.M., Huirne, R.B.M. (eds.) Income stabilisation in European agriculture. Design and economic impact of risk management tools. Wageningen Academic Publishers, Wageningen, pp. 33-53.

14. Zgajnar, J. (2013). Estimating income risk at the pig sector level. Roczniki Ekonomii Rolnictwa i Rozwoju Obszarów Wiejskich, 4, pp. 135-143. 